\title{
FEDERAL SUPERVISION AND REGULATION OF INSURANCE
}

\author{
By S. Huebner, Ph. D., \\ Instructor in Insurance and Commerce, University of Pennsylvania.
}

The agitation for the federal supervision and regulation of the insurance business must be viewed as marking a step in that gradual extension of federal control over industry and commerce which is asserting itself more and more with the increasing intimacy of commercial relations irrespective of state lines, and which is bound to continue until ultimately every important commercial interest whose practice is national in scope shall have been brought within the reach of federal law. Beginning as a local business, insurance has developed into a colossal institution, national and international in scope, and involving, as the President stated in his annual message to Congress, "a multitude of transactions among the people of the different states and between American companies and foreign governments." Into this important field of business, always regarded heretofore as within the control of the several states alone, it is now proposed to extend the power of the national government, and to such an extent that the authority of the states, although not completely eliminated, will becone merely incidental.

Certainly this is a most radical change in view of the vastness of the interests involved. According to recent estimates, ${ }^{1}$ it appears that, even excluding the business of the large number of fraternal beneficiary associations and local mutual fire companies, the amount of insurance in force in the United States aggregates \$50,000,000,ooo, while the assets of the companies have accumulated to the gigantic sum of $\$ 3,000,000,000$. Each year, it is estimated, that the people of the United States, approximately 20,000,000 of whom are directly interested in insurance as policyholders, pay $\$ \mathrm{I}, 000,000,000$ in pre-

1 Majority Report of the Committee on Insurance Law presented at the meeting of the American Bar Association. August 24, 1905. 
mitums to insurance companies, and receive approximately $\$ 800,000$,$\infty 00$ in return. The magnitude and importance of the business as indicated by these figures can scarcely be comprehended, and, being in the main a business of trust, the necessity for strict government supervision must be apparent. Indeed, the supervision of insurance by the government is to-day regarded as an absolute necessity by every authority on the subject, and is considered even more essential than in the case of banks. Insurance contracts, especially in life insurance, may run for years before maturing, the possibility always presenting itself of a company promptly paying its current claims, and yet being hopelessly insolvent as regards its future obligations. Moreover, it is practically impossible for the individual to determine for himself the financial standing of the company into whose care he has entrusted the protection of himself and family, into whose coffers he has paid his premiums for years, and upon whose ability to pay when the time comes he implicitly relies. The only way to determine the solvency of an insurance company is to calculate the present worth of its future obligations, and to compare this and the accrued liabilities with the available assets. This is a task beyond the power of individuals, many of whom have little information about insurance except the name of the company whose policy they hold. It is a task which can be adequately undertaken only by the government; but, while there is a consensus of opinion regarding the necessity of government supervision, the question as to whether the supervising authority ought to be the nation or the several states has been a disputed one for over forty years, and , as we shall see, is still far from settlement.

\section{Historical Review of the Subject. ${ }^{2}$}

The question of national versus state regulation of insurance may be said to have had its origin in the passage of the National Banking Act of r864. Although applying only to banks this act suggested the possibility of extending federal control to the insurance business. In the very next year Congress was memorialized by certain companies to free them from many of the vexatious burdens connected with state supervision. It was proposed in the

${ }^{2}$ For a detailed account of the history of this subject see John F. Dryden's "An Address on the Regulation of Insurance by Congress," delivered at a meeting of the Boston Life Underwriters' Association, November 22, 1904. 
memorial that Congress should pass a national incorporation act which would enable insurance companies, like national banks, to become federal institutions. A bill to this effect was introduced in the Senate in I868, but met with the fate that awaits any measure which attempts to take away the constitutional right of the several states to create corporations engaged in interstate commerce. But while this bill received little support, it is important to note that at this early date, when insurance was much more in the nature of a local institution than now, national supervision, nevertheless, claimed among its supporters some of the most influential men connected with the insurance business. Mr. Elizur Wright, for example, often called the father of state insurance supervision, upheld federal control most vigorously upon the ground that it would greatly simplify matters and be much more economical than state regulation; that it would protect the policyholders equally well, if not better; and that insurance was, by its very nature, a national interest and better adapted to federal than local control.

In the same year that the bill providing for the national incorporation of insurance companies was introduced, there occurred another event which completely changed the status of the problem of national supervision, and which has been inseparably connected with the discussion of the subject from that date to this. This new factor was the famous case of Paul vs. Virginia, decided by the United States Supreme Court in $\mathrm{I} 868$, and confirmed in later decisions, according to which the issuance of a policy of insurance was declared not a transaction of commerce and therefore not subject to federal control. Although this case, as well as those that followed, did not bear directly on the point at issue, the opponents of national supervision have always assumed that in view of these decisions, the Supreme Court would declare unconstitutional any act seeking to deprive the states of their present right to supervise that part of the insurance business which is interstate in character.

The unfavorable decision of Paul vs. Virginia and the defeat of the bill of $\mathrm{t} 868 \mathrm{did}$ not, however, crush the movement for federal regulation. For the next twenty-five years its advocates waged an educational campaign which resulted, at least, in the development of a most extensive literature on the subject. Finally, in 1892 , things seemed ready for another attempt at congressional legislation. In that year Mr. John N. Pattison, president of the Union Central Life 
Insurance Company, introduced a bill providing for a system of national regulation of insurance companies engaged in interstate business. Such companies were to report to a National Bureau of Insurance, and were thereafter to be exempt from all other requirements except those which Congress or the states from which they had secured their charters might see fit to impose. Owing, howcver, to its being weighted down with too many provisions of detail, the bill invoked sufficient opposition to prevent its becoming a law. In 1897 the matter once more came before Congress in the form of the "Platt Bill," modelled closely after the "Pattison Bill" of I892, but again, owing largely to the pressure of other business connected with the Spanish-American War, the bill failed to secure favorable action.

The next important step in the movement for federal supervision was the establishment of the new Department of Commerce and Labor on February I4, I903. This department was authorized, through the Bureau of Corporations, "to gather, compile, publish and supply useful information concerning such corporations doing business within the limits of the United States, as shall engage in interstate commerce or in commerce between the United States and any foreign country, including corporations engaged in insurance." While not of far-reaching importance, this act, nevertheless, meant an advance, since it marks the first successful attempt on the part of the federal government to recognize insurance as a business which demands national and not merely local attention. Then on December 8, 1904, followed President Roosevelt's message to Congress in which he declared insurance to be a business which "vitally affects the great mass of the people of the United States and is national and not local in application," and in which he urged that "Congress carefully consider whether the power of the Bureau of Corporations cannot constitutionally be extended to cover interstate transactions in insurance." Following this expression of Executive approval came the bill of December I2, I904, introduced in the House by Mr. Edward Morrell, but which was referred to the Committee on Interstate and Foreign Commerce. Lastly, we have the bill introduced in the Senate by Mr. John F. Dryden, president of the Prudential Insurance Company of America. This bill marks the latest attempt to secure national supervision through congressional action, and represents better than all former bills the present-day requirements of such legislation.

[684] 
Briefly summarized, the bill introduced by Senator Dryden provided for an official in the Bureau of Corporations called the Superintendent of Insurance. This official was to be appointed by the President and placed in charge of a bureau called the Division of Insurance, and was to be assisted by an official known as the National Actuary. Policies of insurance were deemed by the bill to be "articles of commerce and instrumentalities thereof," and the delivery of contracts of insurance or the transmisson of premiums or other sums between the several states or between this nation and other nations were declared transactions in interstate or foreign commerce. Express provision was made, however, that "the provisions of this act shall not apply to any corporation transacting the business of insurance exclusively within one state, district or territory: and provided further, that this act shall have no application to any religious, charitable, benevolent or purely fraternal society or association." The superintendent of insurance was authorized to require reports in any form he might choose to prescribe from the various companies transacting an interstate or foreign insurance business, and might also examine the business of such companies whenever he saw fit. Every company was to file with the superintendent a certified copy of its charter and by-laws together with its last statement, and was also to make a deposit with the Treasurer of the United States, as a guarantee for the faithful performance of its contracts, United States bonds or otheri securities satisfactory to the superintendent to the amount of $\$ 100,000$, unless the superintendent would accept as satisfactory a similar deposit in the state where the company had secured its charter. After all these requirements had been complied with, the superintendent was to grant a license to the company authorizing it to transact such interstate or foreign business in any or all parts of the Union. Provision was also made that if a foreign nation should refuse American companies such a license or should subject them to rules and regulations different from those applying to companies having their origin in the said foreign country, then the superintendent was to refuse such a license to the companies of that country transacting or seeking to transact business here, and was to subject them to the same rules and regulations applied by the foreign country against American companies.

Although containing many admirable provisions, the bill, as outlined, was introduced too late in the session to secure proper consid- 
eration. There is every reason to believe, however, in view of the President's attitude on the question, and the increasing demand for such legislation, that the same or a similar bill will be introduced in the coming Congress. All previous attempts to secure federal control of interstate insurance, it is true, have come to naught. But at the same time it cannot be denied that public sentiment is steadily growing in favor of federal supervision. To quote the Committee on Insurance Law of the American Bar Assoociation: "No one has offered any substantial reason against federal supervision and it is advocated by the President of the United States, and many state insurance commissioners, and favored by leading insurance officials and numerous insurance journals. Besides these, the general press is in favor of any movement in the direction of greater corporate publicity, and the patrons of insurance-the people-favor federal supervision of the business as the national banks are supervised."3

\section{Arguments in Favor of National Supervision.}

But what are the reasons, it will be asked, which are thus moulding public sentiment in favor of national supervision? A full answer to this question is quite impossible for the present, since the arguments which have been advanced from time to time are exceedingly numerous. Briefly stated, the principal arguments are:

I. That national supervision will greatly lessen the unnecessarily iarge cost of supervising insurance companies by fifty-two separate state and territorial departments, and that by thus lessening the expense it will decrease the cost of insurance.

2. That it will obviate much of the burdensome and discriminatory taxation now imposed by the several states upon insurance companies of other states.

3. That it is the only means of remedying the present lack of uniformity in our state insurance laws; that it will be a step toward uniform regulation and supervision of insurance companies; and that it will afford relief from the many petty exactions imposed by the different state departments, as well as from the evils resulting from variations in the rulings of the several insurance commissioners.

4. That it will afford better protection to policyholders, and will result in the elimination of fraudulent insurance enterprises.

- Page $s$ of the Report of the Committce nn Insurance Law, presented at the meeting of the American Bar Association at Nartagansett Pier, R. I., August 24, 1905. 
5. That it will entitle any insurance company reporting to the national government to transact business in all parts of the Union, at the same time protecting that company against the retaliatory iegislation of other states.

6. That foreign countries would regard with much more weight the certificates issued by a national department, and that the federal authorities would be in a much better position both to protect American companies transacting business abroad and to supervise the large number of foreign companies transacting business in the United States.

7. That centralized supervision by trained experts would enable the national government at small expense to provide for a much greater degree of publicity as regards this most important business than is possible at the present time. Information regarding the principles, operation and condition of the business could be disseminated throughout the country in clear and concise form as contrasted with the confusing, voluminous and often meaningless mass of statistics issued from time to time by many of the state insurance departments.

8. That insurance is both in theory and in practice a national and international business, and not a fit subject for state or local control.

Directing our attention to a more detailed examination of the above contentions, it would seem to require but little argument to show that state supervision and regulation has proved needlessly burdensome and expensive. Although an institution which does not create wealth, but merely equalizes misfortune and aims to protect the individual and the family against loss, insurance has, nevertheless, been subjected to a multitude of taxes and fees, until to-day it is estimated that the business contributes the enormous sum of between $\$ 20,000,000$ and $\$ 25,000,000$ annually to the treasuries of the various states. Nor does this enormous charge bear any direct relation to the service rendered by the states in the way of supervision. Instead, it appears from a recent compilation of data furnished by twenty-eight states, that, exclusive of all taxation, over $\$ 5,000,000$ more was collected by these states than was needed to defray the cost of supervision. In England for example, efforts are made to encourage a business so essential to the family and the state and so promotive of the community's interests as insur- 
ance, by exempting a portion of every income if expended for that purpose. In the United States, however, despite the fact that insurance is itself a tax which in the end must fall upon the community, and that by protecting the family, encouraging thrift and supporting industry, it relieves the state from large expenditures which would otherwise have to be incurred, the various state legislatures have nevertheless vied with one another in reaching the funds of insurance companies through taxes and fees of every sort and description. In fact, the insurance departments of many states, since they accept without question the examinations made by a few of the more important states, have become nothing more than salaryearning and tax-collecting agencies. There can be no doubt that if federal control over interstate insurance can be constitutionally established, the large and unequal tax burden upon insurance companies can be largely removed, and existing taxes properly applied. Similarly the expenses of supervising the business through fifty-two separate departments can probably, as has been estimated, be reduced to one-tenth its present amount.

But quite as flagrant as the tax abuse and the large cost of supervising the business is the absolute lack of uniformity in our state insurance laws. If a compilation of these laws were attempted a most curious spectacle would be the result. It would be found that the fifty-two states and territories are all acting along independent lines and that each, as has been correctly said, possesses "its own schedule of taxes, fees, fines, penalties, obligations and prohibitions, and a retaliatory or reciprocal provision enabling it to meet the highest charges any other state may require of companies of other states."

In the field of taxation, for example, there is neither method nor uniformity of rate. Some states will tax premiums after allowing for losses and expenditures within the state, while others will tax gross premiums without any deduction, thus presenting the interesting anomaly of companies being taxed upon their losses and expenses. Again, in addition to the usual property tax, there is the large variety of fees imposed for the right to enter a state to transact business, for municipal licenses, for filing documents, or for licensing agents. Nothing perhaps more forcibly illustrates the unequal and unscientific character of state taxation with reference to the insurance business than the experience of the New York Life 
Insurance Company some years ago. As regards twenty-five states where the insurance in force aggregated $\$ 317,000,000$ the taxes amounted to only $\$ 23,000$, while in the twenty-four other states and territories representing $\$ 3 \mathrm{I} 3,000,000$ of insurance the company paid $\$ 207,000$ in taxes. ${ }^{4}$

In addition to the evils of unscientific and unequal taxation of insurance companies it is also important to remember that the state legislatures at each session enact a multitude of new laws, many of them detrimental to the interests of the public, certainly annoying to the companies, and frequently in direct conflict with the laws of other states. Especially in fire insurance have the evils of state legislation become clearly apparent. Despite the general introduction of a uniform fire policy in the United States, its provisions have given rise to a great diversity of judicial opinion in the several states, so that its provisions mean one thing in one state, another thing in a second state, and are prohibited in a third. At present nearly one-third of the states have anti-compact laws, nearly one-fourth prohibit the use of the co-insurance clause, nearly one-half have enacted valued policy laws, while nearly three-fourths possess retaliatory enactments-all of which legislation can only be characterized as opposed to the underlying principles of insurance, and detrimental to the best interests of the public. Other states, again, seek to prohibit the company from applying for the removal of an action from a state to a federal court on pain of having its license revoked. Then there are the evils resulting from the different rulings and demands of the insurance commissioners of the same state and of the various states. Finally, there is the right, frequently exercised and leading to duplicate and uncalled for examinations, of the various insurance commissioners to examine all companies transacting business in their state whenever they see fit and at the company's expense.

Examples like these might be greatly multiplied, if space permitted, to show the evils of the present system. Suffice it to say that many insurance commissioners are fully aware of these evils, and have not hesitated to declare their views in favor of a change. Even a supporter of state supervision like Mr. S. H. Wolfe, recently expressed his dissatisfaction with the existing system of insurance laws in the following words: "Each state has an insur-

- Fricke's text book on Insurance page I4. 
ance code of its own, and the difficulties and annoyances which insurance companies experience in trying to comply with fifty different sets of laws may well be imagined. There is a crying need for uniformity in this matter, and for a radical change in the laws of all the states. I know of no one state which possesses a code of insurance laws which may even be termed reasonably satisfactory. The insurance business has attained such proportions, and contributes so liberally through taxation to the income of the state, that it is entitled to more equitable and reasonable treatment than it is receiving at present."'s

Whether this state of affairs can be changed under the present system may well be doubted. Certainly the difficulties of unifying and controlling the action of fifty or more legislatures and the same number of insurance departments with reference to the much misunderstood subject of insurance, may well be questioned in view of our past and present experience. It scems to be beyond reasonable doubt that if Congress could constitutionally create a national insurance department, possessed of the same powers now exercised by the fifty-two state and territorial departments, and place it in charge of competent men holding their positions by reason of special fitness rather than political affiliations, much of the heavy and discriminatory taxation, unnecessary expense, and lack of uniformity in legislation and supervision could be eliminated. There can be little doubt also that centralized supervision could be made much more effective than state supervision in extending publicity; in protecting American companies abroad, and supervising foreign companies transacting business in this country; in granting protection to the insurance companies of one state against the retaliatory acts of other states; and in affording additional protection to policyholders by using the strong arm of the federal government in stamping out fraudulent enterprises.

Insurance in Theory and in Practice is an Interstate Business.

Aside from the arguments just advanced in favor of national regulation, it is important to note that insurance is both in theory and in practice an interstate business. To derive the benefit of the

- See S. H. Wolfe's lecture on State Supervision of Insurance Companies in Trz AvNals of the American Academy of Political and Social Science, September, I 905, page I4 I.

[690] 
law of average which fundamentally underlies the successful operation of all forms of insurance, it is essential that the business should be spread over as wide a field as possible. Hence it is that the development of the business has naturally and necessarily been national and international rather than local. In fact, the proportion of insurance written by American companies in the states where they were organized is exceedingly small, while the interstate business and the business transacted by American companies abroad and by foreign companies on American soil is suprisingly large. In life insurance, for example, it appears that in the case of twenty leading companies, transacting nearly nine-tenths of the total ordinary life insurance of the country, only 15.5 per cent. of the total amount of their outstanding policies is held in the home state, only I4.5 per cent. of the new policies are issued in the home state, and only I 2.6 per cent. of the total premium income is collected there. Even in the case of the four largest companies in America, domiciled in the wealthy and thickly populated State of New York, considerably less than one-fifth of the total business is intrastate, while over four-fifths is interstate and international.

In the case of fire and marine insurance the situation is equally striking. The seventeen largest fire insurance companies of New York, with risks exceeding $\$ 50,000,000$ each and with a combined total of risks aggregating $\$ 5,740,000,000$, wrote only 25 per cent. of their business during 1903 in the home state, and received only 16.7 per cent. of their premium income from the intrastate business. In Pennsylvania the respective percentages for the same class of companies (with risks of $\$ 1,636,000,000$ ) were only 10.5 per cent. and ro per cent.; while in the case of eighteen American companies belonging to the same class, but domiciled outside of New York and Pennsylvania, and carrying risks of $\$ 5,520,000,000$, the proportion of the new business written and the premiums received in the home state amounted to only 5.3 per cent. and 4.9 per cent. of the total. Likewise in the list of marine, casualty, surety and other forms of insurance, similar ratios will be found as regards the intrastate and interstate business. To this may be added the important fact that the large American life insurance companies transact a considerable portion of their business abroad, and that, on the other hand, a very large proportion of the fire and marine insurance of the country is 
written by foreign companies. At the close of 1903 two companies alone (the Equitable and Mutual Life of New York) held 366,725 policies abroad, aggregating $\$ 980,055,792$ of insurance and representing for that year a premium income of $\$ 42,027,980 . "$ During the same year foreign fire insurance companies reporting to the State of New York received $\$ 55,935,772$ in premitums from their American business, or about 28 per cent. of the total premiums collected by all stock companies in the United States, and carried $\$ 7,306,000,000$ of risks, or 27 per cent. of the total. Likewise in marine insurance the American branches of the twenty leading foreign companies wrote $\$ 3,723,000,000$ of risks in 1903 , or 54 per cent. of the total, and received nearly one-half of the total premiums collected. Indeed, in some sections like the Gulf States and the Pacific coast, approximately four-fifths of the total marine insurance written is controlled by foreign capital.

The following tables will show in greater detail the interstate and international character of the insurance business.

\section{Arguments Advanced Against National Supervision.}

Without attempting to disprove, but generally admitting the criticisms directed against the present system of state supervision, the opponents of federal control question the wisdom of enacting legislation to this effect, on one or more of the following grounds:

I. That national supervision would be an undue infringement upon state rights.

2. That the National Convention of Insurance Commissioners is composed of members who are educated to the work, and that it would be better policy to let these commissioners in general assembly continue to provide rules for the regulation and supervision of insurance, as they have been doing for over a quarter of a century.

3. That national supervision will increase the chances for fraud by placing too much power in the hands of a few individuals. The constantly changing character of the heads of the many state insurance departments is one of the most desirable features of the present system, since it renders collusion easy of detection.

4. That the supervision of all insurance companies in the United States, involving such enormous financial interests and embracing

- James M. Beck, North American Review, August, r905, page ig4.

$[6,2]$ 


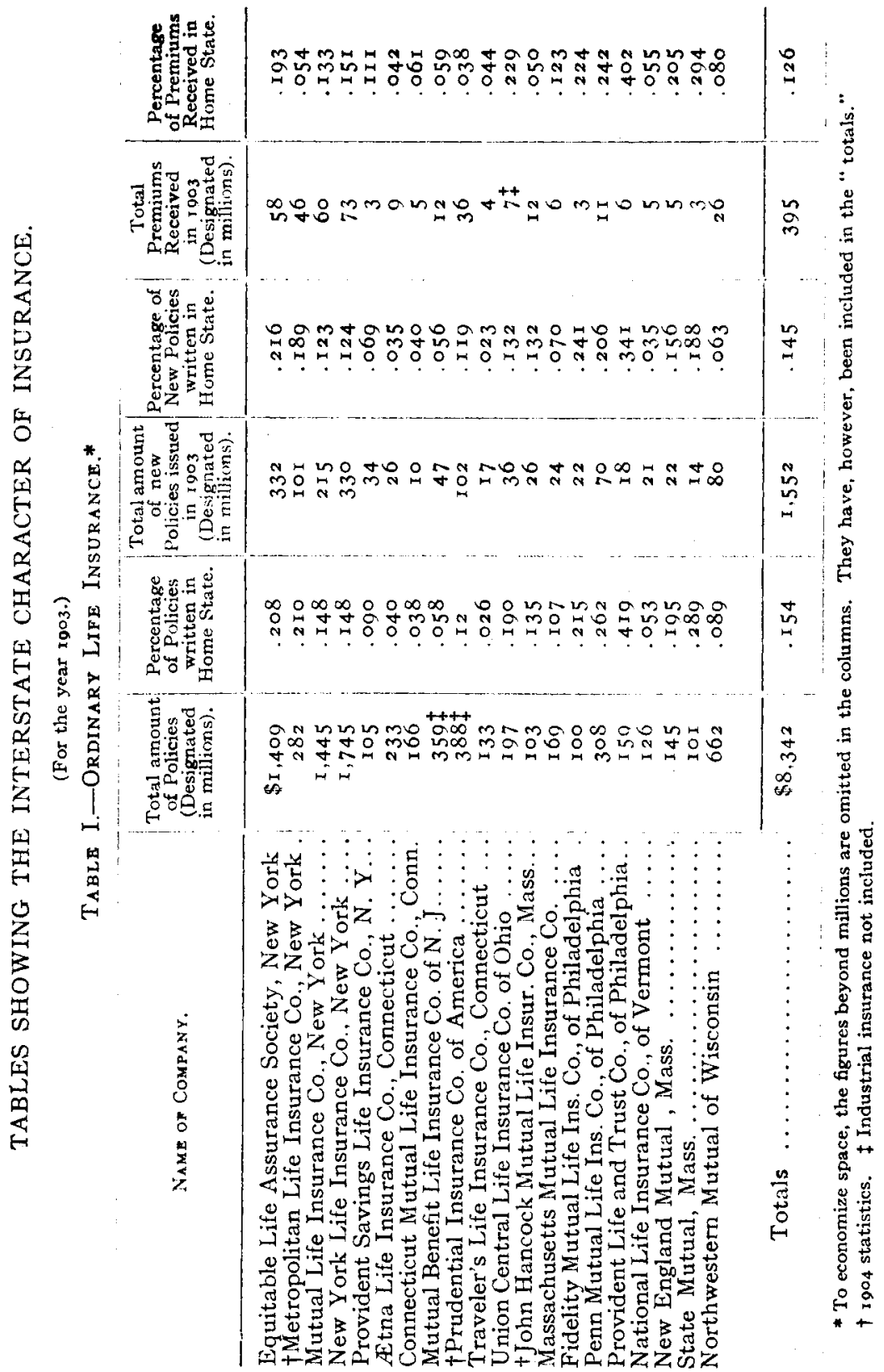

[693] 
TABLE II.-FIRE InSURANCE.*

\begin{tabular}{|c|c|c|c|c|}
\hline & 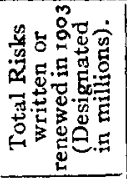 & 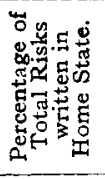 & 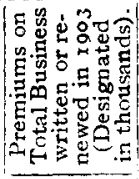 & 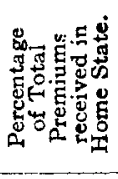 \\
\hline \multicolumn{5}{|l|}{ New York Joint Stock Companies. } \\
\hline Agricultural Insurance Co. ....... & 162 & .246 & $\mathrm{I}, 788$ & .197 \\
\hline Continental Insurance Co. ...... & 661 & .229 & $6,8 \mathrm{r} 8$ &. I 58 \\
\hline Dutchess Insurance Co. ........... & 53 & .362 & 694 & .302 \\
\hline German Alliance Insurance Co........ & 50 & $\cdot 334$ & 541 & .252 \\
\hline German-American Insurance Co..... & 757 & .240 & 7,649 & .15 \\
\hline Germania Fire Insurance Co. . . . . . . & 280 & $.25 \mathrm{I}$ & 2,7 I 7 & .165 \\
\hline Glens Falls Fire Insurance Co. $\ldots \ldots$ & I 35 & $.2 \mathrm{I} 4$ & 1,679 & .140 \\
\hline Globe and Rutgers Fire Insurance Co. & I3 I & . I79 & 2,015 & .164 \\
\hline Greenwich Fire Insurance Co. . . . . . & 269 & .44 & 2,457 & .227 \\
\hline Hanover Fire Insurance Co. ........ & 435 & $.33 \mathrm{I}$ & 4,253 & .331 \\
\hline Home Insurance Co. . . . . . . . . & 1,169 & .266 & I I, 9 I I & .167 \\
\hline Niagara Fire Insurance Co. $\ldots \ldots \ldots$ & 277 & .223 & 3,353 & .161 \\
\hline Phoenix Insurance Co. $\ldots \ldots \ldots \ldots$ & $57 \mathrm{I}$ & .203 & 6,440 & $\therefore 108$ \\
\hline Co. of America .. & 308 & . I39 & 3,983 & .075 \\
\hline $\bar{R}$ Rochester-German Insurance Co. . . . & I IO & .103 & $\mathrm{I}, 477$ & $.07 \circ$ \\
\hline Westchester Fire Insurance Co. ..... & $24 \mathrm{I}$ & .278 & 2,667 & .192 \\
\hline Williamsburg City Fire Insurance Co. & 126 & .377 & 1,351 & 234 \\
\hline Totals & 5,740 & .252 & $61,8 \circ 3$ & .167 \\
\hline \multirow{2}{*}{\multicolumn{5}{|c|}{$\begin{array}{l}\text { Pennsylvania Joint Stock Companies. } \\
\text { American Fire Insurance Co. ....... }\end{array}$}} \\
\hline & 161 & $.15 \mathrm{I}$ & 2 & .135 \\
\hline Fire Association of Philadelphia .... & 403 & .094 & 5 & .085 \\
\hline Insurance Co. of North America .... & $55^{\circ}$ & .096 & 6 & .010 \\
\hline National Union Fire Insurance Co. .. & 105 & .132 & $\mathbf{I}$ & . 128 \\
\hline Penn Fire Insurance Co $\ldots \ldots \ldots \ldots$ & 301 & .108 & 3 & .096 \\
\hline Spring Garden Insurance Co. . . . . . & I I 4 & .086 & I & .087 \\
\hline Totals. & 1,636 & .105 & 20 & . IO \\
\hline \multicolumn{5}{|l|}{ Stock Companies of Other States. } \\
\hline Etna-Hartford, Conn. .......... & 521 & .030 & 7 & .021 \\
\hline American Central Ins. Co. (Mo.) & 200 & .076 & 2 & .084 \\
\hline American Insurance Co. (N. J.) $\because$ & 207 & .093 & 2 & .055 \\
\hline Citizens' Insurance Co. of Missouri .. & 143 & .055 & 2 & .049 \\
\hline Connecticut $\mathrm{F}$ & $26 \mathrm{I}$ & .020 & 3 & .016 \\
\hline Firemen's Fund (California) . & 304 & .088 & 4 & .119 \\
\hline German Insurance Co. (I11.) .... & $26 \mathrm{I}$ & .159 & 3 & .143 \\
\hline Hartford Fire Insurance Co. (Conn.). & $9 \circ 7$ & .012 & I 2 & .010 \\
\hline Milwaukee Mechanics Insurance Co. & 137 & .095 & I & .092 \\
\hline National Fire Ins. Co. of Hartford. . . & 486 & .020 & 5 & .015 \\
\hline \multicolumn{5}{|l|}{ Northwestern Nat'l Insurance Co. of } \\
\hline Milwaukee $\ldots \ldots \ldots \ldots \ldots \ldots$ & 155 & .089 & $\mathbf{I}$ & .088 \\
\hline nce Co. (Conn.) .. & II 7 & .042 & $\mathbf{I}$ & .024 \\
\hline Phoenix Insurance Co. (Conn.) . & 484 & .020 & 4 & .020 \\
\hline Providence-Washington Ins. Co. . & 202 & .033 & 2 & .028 \\
\hline \multirow{2}{*}{\multicolumn{5}{|c|}{$\begin{array}{l}\text { Springfield Fire and Marine } \text { Ins. Co } \\
\text { (Mass.) } \ldots \ldots \ldots \ldots \ldots \ldots \ldots\end{array}$}} \\
\hline & 361 & .052 & 4 & .044 \\
\hline \multirow[t]{2}{*}{ Traders' Insurance Co. (II1.) $\ldots \ldots$. } & I 5 I & .133 & 2 & I30 \\
\hline & 5,220 & .053 & 65 & .049 \\
\hline
\end{tabular}

* To economize space, the figures beyond millions are omitted in the columns. They have, however been included in the " totals." 
over a dozen kinds of insurance differing radically from one another in many respects, is well-nigh beyond the power of a single department.

5. That Congress is without constitutional power to establish a system of federal control.

To understand the real force of these contentions a few words of explanation are necessary. In the first place federal supervision does not contemplate the elimination of state supervision. It seeks only to regulate insurance transactions between the states, and proposes not to interfere with a state's constitutional right to supervise its own home companies. In other words, there is to be federal control over interstate insurance supplemented by state control over domestic companies. Secondly, it should be noted that the National Convention of Insurance Commissioners is only a voluntary body without legal existence. Despite its long career and the great amount of good which it has accomplished, the evils of state supervision are still so numerous and apparent as to preclude any hope for permanent and far-reaching reform so long as this reform must emanate from half a hundred independent sovereignties.

The next two objections to national supervision, namely, the increased opportunity for fraud and the difficulty of supervising such vast interests through a single department-if valid at allshould only serve to caution Congress to exercise the greatest care in providing for the proper organization and administration of a national system. Probably no factor is more largely responsible for present evils than the political character of the state insurance departments. In nearly every state of the Union this department, which above all others, owing to the character of the institution which it represents, should be kept out of politics, is regarded as a part of the state's political machinery to be filled every few years by men who have rendered political services, irrespective of what their qualifications for the office may be. If federal supervision is constitutionally possible, a splendid opportunity presents itself to lift this most beneficient of institutions out of the realm of politics and bring it under the salutary influence of trained officials who might continue to serve through administration after administration.

The last objection is by far the most important, and for years has proved the stumbling block in the way of federal regulation. To bring insurance within the reach of the federal government, 
like the railway industry, it is necessary to show that insurance companies, like railroad companies, are transacting an interstate commerce business. And here we are told that the United States Supreme Court has repeatedly declared insurance not to be commerce. In fact, this objection was the only one offered against national supervision in the minority report submitted by Mr. W. R. Vance to the Committee on Insurance Law before the American Bar Association. ${ }^{7}$ This minority report presents the whole contention in a nut-shell. "I feel myself compelled," writes Mr. Vance in this report, "to dissent from the conclusions reached by my associates of the committee on the single proposition that 'there is no constitutional obstacle in the way of federal regulation' of the business of insurance. If insurance is not interstate commerce, it is clear that the regulation and control of the business is beyond the power of the federal government. I am of opinion that the existing methods of regulating insurance business by the several states is most defective, since it is both inefficient in preventing wild-cat companies from engaging in the business and also nedlessly expensive to those who in the last analysis bear the expenses incident to the business, - the policy-holders. I am also of opinion that federal supervision, if it were possible under our constitution, would probably remedy many of the evils existing under the present system of regulation, but I do not see that such supervision by the federal government is possible without a constitutional amendment expressly giving it the required power. . . . The proper conclusion seems to be that, however much we may desire to believe that insurance is interstate commerce and therefore susceptible of federal supervision, the matter is concluded by the carefully considered judgment of the Supreme Court of the United States against which, despite frequent assaults by its ablest opponents during a period of nearly forty years, not a single dissenting voice has been raised from the bench. Any act of Congress, with a view to such supervision, would necessarily be unconstitutional and void, and the time and money that would be required to secure its passage could much more profitably be expended in endeavoring to secure some uniform action on the part of the states based upon a more intelligent understanding of the business and of the real interests of the insuring public."

T Meeting at Narragansett Pier, R. I., August 24, 1905. 


\section{The Constitutionality of National Supervision.}

The constitutional objection in the way of federal regulation consists of the right of the several states to exercise all those superviscry powers not delegated to the United States by the Federal Constitution. Under the Ninth and Tenth amendments, it is provided respectively that: "The enumeration in the Constitution, of certain rights, shall not be construed to deny or disparage others retained by the people"; and "The powers not delegated to the United States by the Constitution, nor prohibited by it to the states, are reserved to the states respectively, or to the people." In view of these reservations, federal supervision of insurance is clearly impossible unless it is one of the powers delegated to the United States by the Constitution, and the clause which has been generally agreed upon as delegating such power-if it is delegated at all by the Constitution-is Section 8 of Article I, namely: "The Congress shall have the power to regulate commerce with foreign nations, and among the several states, and with the Indian tribes." To utilize this "commerce clause" for the desired purpose, it is necessary to show that insurance is interstate commerce. Unfortunately, however, for the advocates of national supervision the United States Supreme Court has handed down a long series of decisions denying that insurance is commerce. ${ }^{8}$ In the famous case of Paul a's. Virginia, decided in 1868 , the court held that fire insurance was not commerce; then in the case of Hooper ws. California, decided in 1894 , marine insurance was declared not to be commerce; finally in the case of the New York Life Insurance Company r's. Cravens, decicled in I899, life insurance was also held not to be conmerce.

In the case of Paul ws. Virginia, where fire insurance was the subject involved, Justice Field delivered the opinion to the effect that, "Issuing a policy of insurance is not a transaction of commerce. The policies are simple contracts of indemnity against loss by fire, entered into between the corporations and the insured, for a consideration, paid by the latter. These contracts are not articles of commerce in any proper meaning of the word. They are not subjects of trade and barter offered in the market as something having

8 Among the principal cases are Paul 215. Virginia, 8 Wall. 168 (1868); Liverpool Insurance Co. vs. Mass., yo Wall, 566 (1870); Hooper v's. California, iss U.S. 649 (1894): New York Life Insurance Co. vs. Cravens, i 78 U.S. $38_{9}$ ( 1890 ); Nutting 25. Mass. $1 \&_{3}$ L. S. 553 (1001). 
an existence and value independent of the parties to them. They are not commodities to be shipped or forwarded from one state to another, and then put up for sale. They are like other personal contracts between parties which are completed by their signature and the transfer of the consideration. Such contracts are not interstate transactions, though the parties may be domiciled in different states. The policies do not take effect-are not executed contractsuntil delivered by the agent in Virginia. They are, then, local transactions and are governed by the local law. They do not constitute a part of the commerce between the states any more than a contract for the purchase and sale of goods in Virginia by a citizen of New York, whilst in Virginia would constitute a portion of such commerce." In the case of Hooper ws. California, in I894, the court reiterated its opinion in the following words: "The business of insurance is not commerce. The contract of insurance is not an instrumentality of commerce. The making of such a contract is a mere incident of commercial intercourse, and in this respect there is no difference whatever between insurance against fire and insurance against the perils of the sea." Even as late as I9OI, in the case of Nutting vs. Massachusetts, the Supreme Court again confirmed its former decisions, with the words: "A state has the undoubted power to prohibit foreign insurance companies from making contracts of insurance, marine or other, within its limits, except upon such conditions as the state may prescribe, not interfering with interstate commerce. A contract of marine insurance is not an instrumentality of commerce, but a mere incident of commercial intercourse."

\section{Contending Views as to the Applicability of the "Insurance Cases" to the Question at Issue.}

Notwithstanding the numerous decisions in which the Supreme Court has denied to insurance the character of commerce, and which many regard as a final expression of the Court's opinion, there are those who maintain that these cases must not be considered as conclusive against national supervision. In the first place, they contend that none of the insurance cases involved the constitutionality of a federal law. In nearly all the cases the principal question at issue was the validity of state statutes prescribing certain terms, compli- 
ance with which was necessary on the part of foreign corporations before being permitted to transact business in those states; and the statutes were upheld as a legitimate exercise of the police powers. The decision in Paul vs. Virginia that insurance is not commerce, they regard as mere dictum and as not having been essential for the judgment rendered in that case. At the time the accepted doctrine was that the states, in the absence of congressional legislation, had the power to regulate the business of foreign corporations within their borders. Since Congress had not acted, the states were entitled to do so, and even if the court had declared insurance to be commerce, the judgment in Paul vs. Virginia must have been the same. In other words, this case, and those which followed, were based upon state and not federal statutes. Until Congress enacts a law providing for the regulation of insurance companies, the constitutionality of federal supervision must necessarily be viewed as an unsettled question, and no more weight can be given to the opinions expressed in the insurance cases on the nature of the insurance business than is usually attached to judicial opinions on matters that do not necessarily enter into the case under consideration.

Furthermore, the advocates of national supervision point out that the Constitution must be regarded as a growth, and as having undergone a constant evolution. Of no clause in the Constitution is this so true as the so-called commerce clause. From time to time the powers delegated to the federal government under this clause have been expanded so as to meet the new requirements of industrial and commercial progress. While the wording of the clause has not been changed, its operation has been extended to a vastly larger field than formerly, until to-day national control over interstate commerce means an entirely different thing than it meant to our forefathers, and, in view of its gradual extension to new modes of commerce, will mean something entirely different in the future than it does to-day.

There are reasons, the advocates of national supervision assert, which may lead us to believe that the Supreme Court has already in large measure retracted from the position taken in the case of Paul vs. Virginia. It is pointed out $^{9}$ that as early as 1877 , in the case

- Report of the Committee on Insurance Law before the American Bar Association August 24, 1905. Page 8. 
of the Pensacola Telegraph Company vs. Western Union Telegraph Company ( 96 U. S. I), the Supreme Court decided that a New York corporation had the right to construct and operate a line in certain parts of Florida, despite the fact that the Pensacola Telegraph Company had received from the legislature of Florida the sole right to erect and operate a line within.said parts of Florida's territory. The court said: "We are aware that in Paul vs. Virginia this court decided that a state might exclude a corporation of another state from its jurisdiction, and that corporations are not within the clause of the Constitution which declares that the citizens of each state shall be entitled to all privileges and immunities of citizens in the several states.' . . . Upon principles of comity, corporations of one state are permitted to do business in another unless it conflicts with the law or unjustly interferes with the rights of the citizens of the state into which they come. Under such circumstances, no citizen of a state can enjoin a foreign corporation from pursuing its business." 10

More recently we have the decision, in February, 1903, in the so-called "lottery cases," which involved the constitutionality of a federal statute forbidding interstate carriers to transfer lottery tickets between states. It was argued that since an insurance policy had been declared not an article of commerce, a lottery ticket would likewise not come within this category. The Supreme Court, however, by a vote of five to four, upheld the statute and declared a lottery ticket to be an article of commerce. The force of this decision as weakening the authority of Paul vs. Virginia has been clearly expressed by Mr. James M. Beck in the following statement: "Apparently, there was no logical distinction between the two; for, if the lottery ticket, forbidden by the police laws of nearly evry state, which only promises to pay upon the remote contingency of a successful drawing, can be an article of commerce, then a contract of insurance, which promises to pay upon a contingency which must surely happen. must a fortiori be a subject of commerce. . . . It is significant, although the opinion of the minority justices referred at length to Paul vs. Virginia, and subsequent cases as inconsistent with the de-

10 This decision was dissentcd from by Mr. Justice Field, who upheld the decision of Paul vs. Virginia, and urged the necessity of leaving with the states the power to control corporations transacting business within their borders. He argued that "By the decision now rendered, congressional legislation can take this control from the state, and even thrust within its borders corporations from other states in no way responsible to it."

[700] 
cision of the court, the opinion of the majority made no attempt to suggest a logical distinction between a policy of insurance and a lottery ticket; and it may be fairly contended, therefore, until the Supreme Court declares otherwise, that the lottery cases have overruled Paul vs. Virginia, at least to the extent that the former case held that a policy of insurance could not be a subject of commerce."11

The supporters of national supervision, however, do not confine themselves to showing that the authority of Paul vs. Virginia has been impaired by subsequent decisions, but also contend that in neither this nor in any of the other cases is there any record to show that there was any thorough consideration of the facts regarding the character and uses of insurance or the operation of the business. Such a consideration, they say, will show that instead of being a mere incident of commerce as the court has decided, insurance is unquestionably commerce itself or an inseparable element of commerce, as that term is commonly used; moreover, that the court in deciding Paul ws. Virginia and subsequent cases, labored under a misconception of the facts governing the operation of the insurance business.

A closer examination will show that this contention is well substartiated by facts. It requires little argument to prove that insurance fundamentally underlies all business, and that it is inseparably interwoven with our whole commercial life. Marine insurance, for example, is considered an indispensable necessity by all oversea merchants, and in one form or another has become an integral part of nearly every maritime transaction. It ranks in importance with any other active force in influencing and controlling the employment of shipping. It serves a most useful purpose in promoting commercial transactions by vastly extending the use of credit. It is just as much an instrumentality of commerce and almost as essential to international and coastwise trade as the vessel itself.

Similarly in the case of fire insurance, the usefulness of the business to trade and industry can scarcely be comprehended. Without it the business man could obtain no credit, and would be compelled to limit his commercial transactions to the extent of his capital. With fire insurance as collateral, however, he may secure credit from the wholesale merchant or the banker to four or five times the extent of his capital, and do so at cash prices. An American cargo, for exam-

"North American Review, August, 1905, page 190. 
ple, shipped to Europe may be balanced by a European cargo shipped to the Orient, which in turn is balanced by an Oriental cargo shipped to America-a series of transactions based solely on credit, and made possible only because this credit is guaranteed by fire and marine insurance. Illustrations of this nature might be indefinitely multiplied to show how intimately commerce and the various forms of property insurance are related. Suffice it to say that the two cannot be separated. As collateral security, the value of insurance to commerce is beyond all calculation, as may be judged from the fact that 97 per cent. of the world's commerce is estimated to be transacted on credit, and only 3 per cent. on a cash basis. As Mr. A. C. Campbeil has so admirably stated :12 "No statistics would be possible to show the extent of the fire insurance business as now practised, for those figures would need to be as large as those of all trade. There is practically no combustible property that is not insured against fire; every car of grain, every scow-load of lumber, every bale of cotton, every package of manufactured goods, from the time it assumes merchantable shape until it is entirely consumed, is thus conditionally the property of insurers. Without such a system, modern commerce would be impossible. The fire insurance policy, or the assignment of certain interest in it, is attached to the mortgage given by the farmer for money to build his new barn; the fire insurance policy is as necessary to the banker as is the warehouse or shipping receipt on the strength of which he advances funds for that magic of commerce, 'moving the crop'; fire insurance is as important to the manufacturer as is the foundation under his factory ; fire insurance is, in fact, the very backbone of that part of our social life which has to do with making, moving and keeping material things."

Quite as important as fire and marine insurance is the third great branch of indemnity, namely, life insurance. Reaching out among the millions of citizens it accumulates their small savings into gigantic funds aggregating hundreds of millions of dollars to be loaned in turn or used as productive capital. In many respects life insurance ranks with the banking business as a financial institution. Being large dealers in mortgages and securities, life insurance companies exert a powerful influence upon the money market; and while not issuing notes for circulation like banks, they issue bonds and

${ }^{12}$ A. C. Campbell in "Insurance and Crime," page $\mathrm{r} 3 \mathrm{r}$.

[702] 
policies which partake of the same nature. Besides serving as a means of protection to the family or to business enterprises, life. insurance policies may be used as collateral, because through their possession the holder can secure credit from his banker, his merchant or the insurance company.

In general, then, insurance in its various forms turns out to be the foundation of credit, and the protector of all commerce, rather than the mere incident of commerce that the Supreme Court has declared it to be. But in view of some of the other transactions which have been declared subjects of commerce by the Supreme Court, it would seem that insurance policies must likewise belong to this category. If telegraph messages, which are neither "subjects of trade offered in the market as something having an existence or value independent of the parties to them" or "commodities to be shipped or forwarded from one state to another and then put up for sale," are articles of commerce, it is difficult to see why insurance policies should not belong to the same class. If a lottery ticket, depending on a doubtful contingency, and failing to meet with Justice Field's definition of an article of commerce, as laid down in Paul vs. Virginia, is commerce, then it seems that a life insurance contract whose fulfillment depends upon a contingency which is certain to happen, must also be a subject of commerce. But even leaving such analogies out of account, Justice Field's opinion that contracts of insurance "do not take effect-are not executed contracts-until delivered by the agent" and are therefore local transactions, does not accord with actual facts, and unduly emphasizes the importance of the delivery of the contract in an insurance transaction. As a matter of fact, in thousands of cases, insurance policies take effect the day the application is made or when the policy is signed by the policy writer at the home office, that is to say, before the policy is delivered. But it is not so much the delivery of the paper which represents the contract as the purpose contemplated in the contract which should claim our special attention. Insurance must be regarded not as the mere delivery of a policy, but as the exchange of an economic good, intangible, it is true, yet real, for a definite consideration; and here perhaps lies the difficulty in seeing that insurance at bottom is an economic good, resembling tangible commodities which are bought and sold. Insurance companies send their agents from state to state and from coun- 
try to country to sell to the public for a stipulated price a certain utility, a right to be indemnified upon the happening of a contingency, or in other words, an economic good. If insurance were not a utility of actual value, there would not be so many millions paying their hard cash in order to obtain it. As has been aptly said :13 "A contract to exchange a ton of coal for money may not be commerce, but the actual exchange is; and, by parity of reasoning, a contract to pay a sum of money for indemnity, in consideration of an ultimate return, whether certain or contingent, of another sum of money, may not be commerce, but the actual exchange of reciprocal pecuniary benefits would seem to be as much commerce as the exchange of any other.commodity."

From whatever point of view we may consider the nature of insurance, it appears, therefore, to be not only an integral and indispensable element of commerce but a subject of commerce itself, as we use that term in everyday language. It is just as much a part of modern commerce as the telegraph, the telephone or transportation itself. Indeed, it is regarded as a part of commerce by nearly all the great nations, for in England the supervision of insurance is entrusted to the Board of Trade ; in Austria to the Tribunal of Commerce; and in France to the Minister of Commerce. Even the Congress of the United States has declared insurance corporations as coming under the term "commerce" by legislating that the Department of Commerce and Labor should gather and distribute information regarding corporations engaged in interstate commerce, including corporations engaged in insurance.

\section{Conclusion.}

From the foregoing review it must appear that the mass of evidence warrants a change from a decentralized to a centralized system of supervision. Indeed, the only important obstacle in the way of such a change is legal and not economic. By its very nature insurance is a national interest, and nearly all students of the subject are agreed as to the advantages of having the business controlled by one central supervising authority. There can be little doubt that a national insurance department, if properly constituted and wisely administered, can greatly reduce the present

\footnotetext{
u James M. Beck in the North American Review, August, rg05, page 201.
} 
expense of supervision, and can do much towards equalizing and lessening the present burden of taxation. There can be little doubt, too, that it is the only practicable means of creating uniformity in our insurance law and in the methods of supervising the companies. It can be made to afford better protection to policyholders than the present system, at the same time protecting the companies from arbitrary, restrictive and retaliatory legislation on the part of the several states. Moreover, as is generally admitted, it could greatly extend the principle of publicity, and could certainly be made to render more effective than the present system the supervision of that large part of the insurance business which is international.

With the single exception of the United States every nation of any importance has recognized the necessity of centralizing control over insurance. The German Imperial Statute of May 12, I90I, placed the supervision of private insurance companies, heretofore regulated by the several states, in charge of an imperial supervising office. The constitution of 1898 of the Commonwealth of Australia likewise vests the control over interstate insurance in the central government; while in France, after a thorough consideration of the subject in 1903, the insurance business was placed under the control of the Ministry of Commerce. Only in the United States is there a decentralized system of fifty-two separate departments regulating and supervising a business which might just as well be taken care of by a single department. And the only important argument which has been advanced against a change ever since I868 and which is being used as effectively now as ever, is the doubtful constitutionality of any measure which seeks to nationalize insurance with reference to its control. But, as stated, the question of the constitutionality of such a measure has never yet been squarely presented to the United States Supreme Court for decision, because Congress has never yet legislated to that effect. In all the so-called "insurance cases" upon which the argument of unconstitutionality is based, some other inmediate issue was involved. The-constitutionality of a law providing for national supervision of insurance is, therefore, an untried and unsettled question, though numerous facts would seem to justify a hope that the Supreme Court would pass favorably upon such a measure. Public policy would seem, therefore, to require that Congress should at the earliest possible moment take the initiative by enacting some measure, like the Dryden Bill, 
thus giving occasion for a test case. Then, if the Supreme Court refuses to reverse its former decisions and Congress is left without constitutional power to establish a law providing for national supervison, the question arises whether the evils of the present system and the advantages of the proposed system, in view of the importance and magnitude of the interests involved, would not justify the adoption of a constitutional amendment.

But in case national supervision of insurance should ever become a reality, it cannot be too strongly emphasized that the nature of the business and the interests of both insured and insurers demand that such supervision should be taken entirely out of politics, and should be entrusted to men who are chosen for their special fitness rather than party allegiance. Few departments of government involve greater responsibility and come into closer contact with the interests of so many millions of people as the insurance departments. Insurance is a technical business which requires that those who look after its financial condition, prescribe its investments, recommend legislation and otherwise regulate the business, should be men with special training and with long experience. Yet under the present system of state supervision this all-important requirement has been largely disregarded and insurance departments have in most cases assumed a distinctly political character. "It will be seen," writes Mr. S. H. Wolfe in a recent article," "that the supervising officer is part of the political machinery of the state, and the besetting sin of American civic government-the political pull-is responsible for whatever lack of efficiency there may be in this important branch of the state government. It is an unfortunate fact that this office, which comes into such close and vital relationship with the interests of so large a number of citizens should be handed out as a reward for political services. It must not be understood that this is a sweeping condemnation of all insurance departments or a denunciation of every insurance commissioner, for some have appreciated the importance of their duties, have cast off all political yokes and affiliations, and have succeeded in reforming serious evils which existed in the business. It is merely a criticism of a system which takes men with no technical education, places them in charge of one of the most important bureaus, and then, without regard to their honesty, efficiency or record, sweeps them out of office and hands their posi-

u North American Revie, July, I905. 
tions to some new, inexperienced man as a reward for political services rendered at the last election. This condition of affairs is to be found in nearly every state in this country. . . . To expect a man trained in other walks of life to develop suddenly into a competent supervisor, is to assume the impossible. Life insurance is a huge structure and its erection must be watched by competent eyes."

Simply to substitute a national department for a large number of state departments without eliminating the present political character of the office, may only be laying the basis for a repetition of many evils which it is now sought to overcome. Centralized supervision, if properly organized and applied, makes possible certain reforms which cannot be realized by attempting to unify the action of half a hundred independent and often hostile legislatures and insurance departments. Quite as important as centralization in supervision is the necessity of making certain that the supervising officers are strong, efficient and politically independent. Only by combining centralization of supervision with these other factors can real and lasting reform be accomplished. 